"Przegląd Prawa Konstytucyjnego"

----- ISSN 2082-1212 ------

DOI 10.15804/ppk.2014.04.12

Nr $4(20) / 2014$

\title{
Sprawozdanie
}

\section{Seminarium dla Uczczenia Pamięci Profesora Marka Sobolewskiego w XXX Rocznicę Śmierci, 17 października 2013 r., Kraków}

W dniu 17 października 2013 r. na Uniwersytecie Jagiellońskim w Krakowie odbyło się seminarium poświęcone pamięci wybitnego uczonego, znakomitego dydaktyka, a także wychowawcy młodzieży akademickiej - Profesora Marka Feliksa Sobolewskiego. Seminarium zostało zorganizowane przez Katedrę Konstytucjonalizmu i Ustrojów Państwowych Instytutu Nauk Politycznych i Stosunków Międzynarodowych UJ we współpracy z Katedrą Doktryn Politycznych i Prawnych Wydziału Prawa i Administracji UJ. Współdziałanie w organizacji wydarzenia dwóch katedr z różnych wydziałów nie może dziwić z uwagi na rozległe zainteresowania naukowe Profesora Sobolewskiego, który skupiając się w swej twórczości na instytucjach i doktrynach zachodnich demokracji XIX i XX w., prowadził badania na styku prawa konstytucyjnego, doktryn politycznych i prawnych, socjologii politycznej i nauki o polityce. Tę imponującą różnorodność dociekań i ich wspólny mianownik celnie oddał Witold Zakrzewski: „W twórczości Marka Sobolewskiego badania instytucji i doktryn wiążą się integralnie w analizę zjawisk politycznych i prawnych traktowanych współzależnie”.

To, co łączy obie katedry, dotyczy również czerpania po dziś dzień z wielkich zasług na rzecz rozwoju życia akademickiego, jakie stały się udziałem Marka Sobolewskiego - współzałożyciela krakowskiego ośrodka nauk politycznych i kierownika Zakładu Historii Doktryn Politycznych po swoim mistrzu, Konstantym Grzybowskim. Szczególnie istotna dla rozwoju politologii

1 W. Zakrzewski, Marek Sobolewski, „Państwo i Prawo” 1983, z. 9, s. 105. 
była działalność związana z pełnieniem licznych funkcji i godności akademickich. W latach 1972-1975 Profesor Sobolewski pełnił funkcję dziekana Wydziału Prawa i Administracji UJ. Po zakończeniu kadencji objął stanowisko dyrektora Instytutu Nauk Politycznych UJ, zwiększając dzięki swoje$\mathrm{mu}$ autorytetowi prestiż jednostki naukowej będącej wówczas ciągle in statu nascendi. Jednocześnie skupił wokół siebie szerokie grono uczniów, którzy teraz, biorąc udział jako prelegenci w obradach seminarium, postanowili uczcić trzydziestą rocznicę przedwczesnej śmierci swego nauczyciela.

Wśród zaproszonych gości seminarium znaleźli się również: prof. dr hab. Krystyna Chojnicka, dziekan Wydziału Prawa i Administracji UJ, dr hab. Arkady Rzegocki, prof. UJ, prodziekan Wydziału Studiów Międzynarodowych i Politycznych, dr hab. Robert Kłosowicz, prof. UJ, dyrektor Instytutu Nauk Politycznych i Stosunków Międzynarodowych UJ. Licznie obecni byli inni uczeni związani z Instytutem Nauk Politycznych i Stosunków Międzynarodowych UJ oraz Wydziałem Prawa i Administracji UJ. Nie zabrakło też doktorantów i studentów.

Uczestników przywitał organizator spotkania prof. dr hab. Andrzej Zięba, kierownik Katedry Konstytucjonalizmu i Ustrojów Państwowych UJ. Uroczystego otwarcia obrad seminarium dokonał prof. dr hab. Andrzej Mania, prorektor UJ ds. dydaktyki.

Seminarium podzielone zostało na dwa panele dyskusyjne. W obu wygłoszonych zostało szereg referatów odwołujących się do bogatego dorobku naukowego Profesora Sobolewskiego. Panelowi przedpołudniowemu przewodniczył prof. dr hab. Henryk Olszewski, uczony związany z Wydziałem Prawa i Administracji Uniwersytetu im. Adama Mickiewicza w Poznaniu, należący do cenionych znawców doktryn politycznych i prawnych. Pierwszy referat pod znamiennym tytułem Mistrz wygłosił prof. dr hab. Jacek Majchrowski, kierownik Katedry Historii Polskiej Myśli Politycznej UJ. Profesor Majchrowski przedstawił najistotniejsze wątki związane z karierą zawodową Marka Sobolewskiego, dorobek naukowy, działalność organizacyjną, a także udział w zagranicznym życiu naukowym, który umożliwiała rzetelność warsztatu naukowego i poszukiwanie nowych, częstokroć kontrowersyjnych tematów posiadających wielką wartość inspirującą. Właśnie ta cecha dorobku Profesora Sobolewskiego chyba najpełniej została wyrażona w następnym wystąpieniu autorstwa prof. dr. hab. Retta R. Ludwikowskiego, dyrektora In- 
stytutu Prawa Porównawczego i Międzynarodowego w Columbus School of Law na Katolickim Uniwersytecie Ameryki w Waszyngtonie, który skupił się na zagadnieniu związanym $\mathrm{z}$ historią i przyszłością filibusteringu w Stanach Zjednoczonych Ameryki.

Kolejna prelegentka, dr hab. Bogusława Bednarczyk, prof. UJ z Zakładu Historii Myśl Politycznej UJ zaprezentowała zagadnienie praw człowieka i ich ewolucji, przypominając rozwijane intensywnie przez swojego Mistrza wielopłaszczyznowe studia nad prawami i wolnościami jednostki. Następnie prof. dr hab. Marian Grzybowski, kierownik Katedry Prawa Ustrojowego Porównawczego UJ, skoncentrował się na problematyce reprezentacji politycznej, podejmowanej przez Marka Sobolewskiego już w początkach swojej kariery akademickiej i stanowiącej następnie przedmiot rozprawy habilitacyjnej: Reprezentacja w ustroju współczesnych demokracji burżuazyjnych (1962). Pierwszą część obrad zamknął referat prof. dr. hab. Andrzeja Zięby, który poświęcił swoje wystąpienie omówieniu fundamentalnych zasad ustroju Zjednoczonego Królestwa, przypominając tym samym nurt zainteresowań Marka Sobolewskiego, który z czasem stał się jednym z kluczowych obok teorii partii politycznych. To zainteresowanie zasadami ustrojowymi państw demokracji liberalnej zaowocowało ważną książką: Zasady demokracji burżuazyjnej i ich zastosowanie (1969).

Drugiemu panelowi przewodniczył prof. dr hab. Krzysztof Pałecki, kierownik Katedry Socjologii Prawa UJ i wieloletni dyrektor Instytutu Nauk Politycznych UJ. Pierwszym prelegentem był prof. dr hab. Michał Jaskólski, kierownik Katedry Historii Doktryn Politycznych i Prawnych UJ. Wystąpienie dotyczyło problematyki systematyzacji doktryn współczesnych na tle rozważań Marka Sobolewskiego i odnosiło się tym samym do zdolności formułowania ujęć syntetycznych charakteryzującej pisarstwo Mistrza. Warto odnotować, że ukoronowaniem zainteresowań Profesora w tej dziedzinie jest wydana wspólnie z Barbarą Sobolewską praca: Myśl polityczna XIX i XX wieku - Liberalizm (1978). Następnie głos zabrał prof. dr hab. Michał Śliwa, rektor Uniwersytetu Pedagogicznego w Krakowie, który omówił zagadnienie parlamentaryzmu w polskiej myśli politycznej okresu międzywojennego. Było to kolejne odwołanie do podstawowego kierunku badań prowadzonych w latach 60. przez Marka Sobolewskiego, jakim było prawo konstytucyjne. W tym okresie kierował baczną uwagę między innymi na sprawy parlamen- 
taryzmu, poddawał analizie funkcje państwa i problem suwerenności, interesował się systemami wyborczymi i stosunkiem reprezentantów do wyborców.

W końcowej części obrad panelowych miały miejsce dwa szczególne wystąpienia. Pierwsze, dr hab. Katarzyny Sobolewskiej-Myślik, prof. UP, kierownika Katedry Organizacji i Ruchów Politycznych w Instytucie Politologii Uniwersytetu Pedagogicznego, dotyczyło stanu badań nad partiami politycznymi w Polsce - dziedziny, w której Marek Sobolewski był jednym z najwybitniejszych specjalistów. Prelegentka zwróciła uwagę na aktualność jednego z najbardziej znanych i cenionych dzieł Profesora: Partie i systemy partyjne świata kapitalistycznego (1974 oraz 1978). Drugie wystąpienie zostało wygłoszone przez prof. dr. hab. Marka Waldenberga, wieloletniego pracownika Instytutu Nauk Politycznych i Stosunków Międzynarodowych UJ. Wybitny uczony, historyk doktryn politycznych i prawnych w ciepłych słowach wypowiadał się o latach współpracy z Profesorem Markiem Sobolewskim, również o jego aktywności społecznej związanej z zamiłowaniem do turystyki i działalnością w Towarzystwie Przyjaźni Polsko-Francuskiej oraz w Towarzystwie Polsko-Austriackim.

Po zakończeniu drugiego panelu obrad uczestnicy konferencji udali się na Cmentarz Rakowicki i złożyli kwiaty na grobie Profesora. Seminarium zakończyło spotkanie w Urzędzie Miasta Krakowa. Uczestników podjął Prezydent prof. dr hab. Jacek Majchrowski, który lampką wina wzniósł toast za pamięć o Profesorze Marku Sobolewskim.

Mateusz Kolaszyński Uniwersytet Jagielloński 